REVISTA de

PEDAGOGIE

\title{
THE EFFECTS OF EXTRACURRICULAR AND EXTRASCHOOL ACTIVITIES ON SCHOOL PERFORMANCE
}

Efectele activităţilor extracurriculare şi extraşcolare asupra performanţei şcolare

\section{Andrea BARABÁS}

\author{
Journal of Pedagogy, 2020 (1), 173 - 192 \\ https://doi.org/10.26755/RevPed/2020.1/173
}

The online version of this article can be found at: http://revped.ise.ro/category/2020/

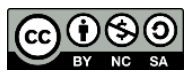

This work is licensed under the Creative Commons Attribution-NonCommercial-ShareAlike 4.0 International License.

To view a copy of this license, visit http://creativecommons.org/licenses/by-nc-sa/4.0/ or send a letter to Creative Commons, PO Box 1866, Mountain View, CA 94042, USA.

Published by:

Centrul Național de Politici și Evaluare în Educație

UNitATEA de CERCETARE ÎN EDUCAȚiE

http://www.ise.ro/

https://rocnee.eu/

Further information about Revista de Pedagogie - Journal of Pedagogy can be found at:

Editorial Policy: http://revped.ise.ro/editorial-policy/

Author Guidelines: http://revped.ise.ro/the-writer-guide-2/ 


\title{
THE EFFECTS OF EXTRACURRICULAR AND EXTRASCHOOL ACTIVITIES ON SCHOOL PERFORMANCE
}

\section{Andrea Barabás*}

\author{
University of Debrecen, \\ Doctoral School of Human Sciences, \\ Debrecen, Hungary \\ andrea.barabas17@gmail.com
}

\begin{abstract}
The socio-economical background of the family influences the school efficiency, but beside this, many other factors have outstanding effect on pupils' results. Most of these factors can be found outside of the educational institutions. The studies which focus on the performance of schooling highlight the idea that extracurricular activities have enormous benefits on the school performance as well as on the overcoming of school failure and abandonment. Our research is focusing on the extracurricular and extraschool activities as well as their effect on the development of competencies. We would like to find out how the extracurricular/ extraschool activities influence the results of competence measurements. We created our background questionnaires, that analyse the effects of influencing factors, since there aren't such questionnaires in the national assesments in Romania. Our study is based on the analysis of the KOV-ET-OM-2017 database $(\mathrm{N}=1054)$, which contains the results of the competency assesment of the 4th grade students belonging of the Hungarian minority from Covasna county and information related to contextual factors from the background questionnaires. The outcome of the research highlights the fact that the extracurricular activities have beneficial effect on the development of the school competences. Among the activities organized by the schools, the camps and the activities supporting the prodigies seem to be the most effective.
\end{abstract}

Keywords: afterschool, extracurricular activities, extraschool activities, school performance.

PhD Candidate, University of Debrecen, Doctoral School of Human Sciences, Debrecen, Hungary. 


\section{Rezumat}

Situa ia socio-economică a familiei influen ează foarte mult performan a şcolară, insă şi al i factori au efecte asupra rezultatelor şcolare. Studiile eviden iază că activită ile extraşcolare şi extracurriculare au beneficii asupra performan ei şcolare, precum şi asupra depăşirii eşecului şi a abandonului şcolar. Cercetarea noastră se concentrează pe studierea efectelor activită ilor extracurriculare şi extrașcolare asupra rezultatelor de la evaluările na ionale de la clasa a 4-a. Intrucât evaluările na ionale nu sunt înso ite de chestionare informative, nu cunoaştem impactul factorilor contextuali asupra rezultatelor elevilor. De aceea, am creat un chestionar care să ne ajute în identificarea factorilor ce influen ează performan a şcolară a elevilor. In acest studiu ne concentrăm pe analiza bazei de date KOV-ET-OM-2017, care con ine rezultatele evaluării competen elor elevilor din clasa a 4-a cu predare în limba minorită ilor maghiare $(N=1054)$ din jude ul Covasna şi informa ii legate de factorii contextuali. Rezultatele cercetării eviden iază faptul că activită ile extraşcolare au efect benefic asupra dezvoltării competen elor şcolare. Dintre activită ile extracurriculare organizate de şcoală se observă efectul pozitiv al taberelor şi activită ilor de dezvoltare.

Cuvinte-cheie: activită i extracurriculare, activită i extraşcolare, afterschool, performan ă şcolară.

\section{Introduction}

International measurements of PISA, PIRLS or TIMSS highlight the strong influence of family background and the fact that Romanian students perform more below average (Singer, 2013). In schools where the proportion of disadvantaged pupils is high, teachers make parents responsible for their child's failure at school (Fehérvári, 2015; Széll, 2015). Students with a poorer socio-economic background often perform poorly. In many places, however, the school would increase the differences from the social background (Fehérvári, 2015; Széll, 2015). In educational contexts where the parent is unable to help the child prepare for the afternoon, the school has an important role to play in increasing student achievement. Positive effects of teachers' well-functioning professional relationships and cooperation can be demonstrated in examining student performance (Bacskai, 2015). In addition to the appropriate teacher attitude, preparedness and quality of classroom activities, extracurricular activities can make a major contribution to academic achievement (Pusztai, 2015), the prevention of early school leaving (MEN- 
MB, 2015ํ) and more successful further education (Széll, 2015).

The use of the results of national competency assessments raises many questions. Although national measurements are taken at the end of grades 2 and 6, feedback is used for individual assessment and is designed to improve student performance and should be used to develop individual learning plans based on the type and amount of defective or unresolved tasks. It is beneficial because it can be motivating for the learner as he/she receives a personalized assessment. But it has little informativeness (Buda, 2011). The most important goal of competency measurement at the end of fourth grade is to evaluate lower-level education - "benchmark student performance against curriculum requirements, measure individual student performance against national average, determine performance improvement attributable to preparatory class introduction, and comparing it with the results of international measurements" (Szántó, 2015, p. 2). It should be mentioned that, while in the international measurements background factors play a central role in the analysis, in Romania there is no background questionnaire focusing on the influencing factors.

In our study, we investigate the relationship between extracurricular, extraschool activities and the result of competence measurements.

There are many definitions in the scientific literature that define activities beyond the boundaries of the curriculum. Thus, in extracurricular activities, we can meet the concepts like all-day school, full-day school, after school, second school, shadow education, which very often overlap or complement each other.

Extracurricular and extraschool activities can produce many positive effects. Part of them are correction, catch-up, compensatory programs, which are used to fill gaps in classroom and overcome social handicaps, the other part is aimed at developing sports activities, physical education, the third type is music literacy, the fourth type is participation in school life, the fifth type is religious or charitable education. The positive impact of extracurricular and extraschool activities in sport, art and science can be directly demonstrated by improved academic performance and successful admission examinations (Pusztai, 2009). 
Extracurricular activities organized in schools are characterized by organized circumstances, multiple purposes and supervision by teachers. They can be nationally sponsored, local initiatives or even organized by schools. Extraschool activities can be varied in their added pedagogical value. Countries that implement systematic school-based programs based on research results can really benefit from these ( $F$ z, 2017). There are studies that show that the extracurricular effect is particularly evident in underperforming students who need correction and compensation (Imre, 2015).

However, we must not forget the fact that coaching, pre-admission, special clubs, camps, excursions, cultural programs are increasingly found in shadow education more than in the extracurricular field within educational institutions.

\subsection{Extracurricular activities}

Báthory (1997) identifies the learning outside school and within school walls as arenas of learning. Within the school, he distinguishes between the curriculum and the extracurricular. The former focuses on curricular learning and the latter refers to learning outside the classroom but within the school walls. It emphasizes the importance of the extracurricular, as it is a proven fact that motivation to learning is not achieved through classroom learning alone. Classroom learning can be completed with other forms and spaces like libraries, laboratories, workshops. In Hungary, the introduction of optional activities has allowed the removal of rigid boundaries and has enabled students, at their choice, to deepen, supplement or even explore new areas of study.

Similar activities can be organized within the framework curriculum hours, which appear as an optional ('optional') subject as part of the local curriculum (Fóris-Ferenczi, 2008; Péter, 2012). In the international research there is a field of specialization that can be regarded as an enrichment program supporting middle-class students rather than as an extracurricular form of training for outstanding students (Gordon Gy ri, 1998). An important feature of talented pupils' development activities is that students can meet peers with similar interests and abilities. These can help them to judge their abilities 
more realistically (Páskuné Kiss, 2014). At the same time, we emphasize that specialization, corrective / compensatory activities and talent development activities help to enhance learning motivation and student performance. In Hungary, religious and community building, sports activities are predominant in church-maintained schools. For those working in these educational institutions, this is a task that requires more preparation and volunteering. Public education focuses mainly on school-related programs. Weekend programs and day trips are much more common in church institutions (Pusztai, 2009).

However, their impact on social skills is only significant if extracurricular activities are regular, lasting, and involve students in collaborative tasks ( $\mathrm{F} \mathrm{z}$, 2018).

\subsection{The all-day school}

The social changes of the last 30 years have confronted educational institutions with new challenges. Increased involvement of parents in the labor market has created a situation in which those who work spend a significant part of their day at work; the number of parents who are unemployed is constantly increasing; the multi-generational, collaborative family model disappears. Globally, it has become necessary to develop and operate a new type of parenting model, integrating and synthesizing the efforts previously pursued by educational institutions and families. In several countries initiatives taken to improve efficiency include the introduction of a all-day school. The allday school aims to achieve equal opportunities so that all children have access to services, some of which can be found in profit-oriented shadow education. Its characteristics distinguish it from programs organized after other classes, as they offer more than one activity (for example, homework solving, art, sports, leisure activities). By merely supplementing what is learned at school, if the activity is purely homework, its beneficial effects are diminished or even eliminated (Darvas \& Kende, 2010; Imre et al., 2015).

The all-day school focuses on making the school with quality classroom and leisure content more efficient. It is part of the development of the education system, but without other pedagogical and infrastructural improvements, it 
alone cannot provide a solution. In most cases, initiatives to extend time frames are not just learning time, school tasks and roles are also often transformed and the relationship between the school and its environment is also reconsidered (Imre et al., 2015). Teacher cooperation is more common in disadvantaged schools where teachers spend more time developing and catching up in order to develop individual students (Bacskai, 2015). It should also be noted that the individual's use of personalized methods (Mihály, 2004) is highly attributed to the effectiveness of teacher work.

Extending teaching time serves a variety of purposes: it can serve to strengthen socialization, increase school performance, and compensate for drawbacks stemming from disadvantage (Imre et al., 2015). The all-day school can be an important institution in overcoming disadvantages and increasing equal opportunities if its content, quality and standard are appropriate (Darvas \& Kende, 2009).

In Romania, the methodology for organizing the 'School after school' program provides the legal framework for organizing the programs. In 2017, methodological changes and additions were made to this methodology. Accordingly, the 'School after School' program is a supplementary compulsory education program aimed at: prevention of early school leaving, increasing school performance, recovery, accelerating the learning process through various learning, educational and recreational activities, personal development, promoting social inclusion; organizing the students' afternoon program in a secure space. The program is open to children in primary and secondary schools, with special attention to vulnerable children. The program is organized by educational institutions in the form of a project based on an assessment of the needs of stakeholders (students, parents, teachers, local community and partner organizations/foundations). Each educational institution must have developed the Operating Regulations for the 'School after school' program ${ }^{2}$. Education and leisure activities are aimed at personal development and social inclusion. However, educational institutions are not obliged to organize an after-school program after school, but in many cases schools do so. The school can do it with parental support, sponsorship, own income, various applications. In schools with a low socio-economic status, county and local governments, foundations and associations support the 'School after School' program. 
In Covasna County this works with the support of the county local government, through applications and sponsored by parents. In order to help children from disadvantaged families, municipalities also provide lunch to students in need. Qualified educators help with the afternoon activities: students solve their homework, participate in teambuilding games and group activities (https://www.kvmt.ro/index.php). Research results show that where there is a possibility to participate in other extra activities throughout the day (special clubs, sports activities, cultural and artistic activities, correction and compensation programs), there is a clear positive effect as opposed to simply preparing for the next day (Darvas \& Kende, 2010; Imre et al., 2015; Pusztai, 2015).

\subsection{The extraschool activities and the shadow education}

Today, there is a worldwide expansion of shadow education. Many people attribute this to the decline in the quality of formal education worldwide and the economic austerity in education. Others, however, explain that the rigid education systems of our accelerated world are not able to respond flexibly to the needs of those involved in education. As the services available in the field of shadow education are not accessible to all due to different socioeconomic backgrounds, Mihály (2004) concludes that shadow education further increases the chances of differences between students from different social background.

According to Stevenson and Baker (1992), shadow education is a nonformal, private education that facilitates the advancement and success of students in the educational system through the effect of coaching, compensating and/or talent gains. They attribute the most prominent development role in talent management to this type of education. Participation in private lessons is usually the result of parental decisions, as every parent tries to choose the best activities for his or her child (Pásku \& Münnich, 2000). Private lessons are additional enriching activities for the development of successful students.

Bray (2010) emphasizes the role of extracurricular activities as a remedy, corrective and repetitive of school learning. However, in underfunded 
educational institutions facing financial difficulties, many extracurricular activities have become optional. In many cases it can be observed that these activities have disappeared completely from school life and can be found in the field of shadow education (Pusztai, 2015).

Worldwide, most of the commercially available out-of-school education and training services, also referred to as 'second schools', operate in the 'forprofit' sector as a private enterprise, but many nonprofit organizations run similar programs (Pásku \& Münnich, 2000). While in the past there was one-on-one training or preparation for exams and competitions, this sector has now reached enormous proportions. Nowadays, during the holidays, programs for similar topics are organized for larger groups. Programs in mathematics, mother tongue and foreign languages have the highest proportion (Bray, 1999).

The main feature of shadow education is that it is complementary to mass education and is intended to increase the student's performance, but has not (yet) created a comprehensive education system. These effects can increase the gap between those with weak and better socio - economic status, even during school breaks, leading to an increase in performance differences (Gordon Gy ri, 2008).

In Romania, there are institutions within the education system that make access to extraschool activities available to everyone free of charge. These institutions, under the name of Children's Palace/ clubs, offer a number of nonformal activities with qualified instructors that would be less feasible within the school walls. The institutions have legal personality and specialize in extracurricular activities that allow them to deepen and enrich children's knowledge. The operation of these institutions is regulated by the 2011 Education Law and the Ministry of Education Decree 4624/2015. Children's palaces and clubs are state educational units, with legal personality, specialized in extracurricular activities, within which specific instructiveeducational actions are carried out, through which knowledge is deepened and diversified, formed, where competencies are developed and practiced according to the children's vocation and option and that capitalize the children's free time by involving them in educational projects. The Education Law considers that non-formal learning is integrated and has learning 
objectives but does not explicitly follow a curriculum and may vary in duration. The activities take place in different organizational frameworks: there may be special clubs, but workshops, laboratories, gyms, sports fields, and camps can also host the programs.

In the field of shadow education, there is even a plethora of programs initiated by associations, museums, foundations, and libraries. In many cases, student participation in extraschool and extracurricular activities appears to be an effective investment in both social and cultural capital (Bourdieu, 1999; Pusztai, 2009).

\section{Methodology}

\subsection{Research questions, hypothesis}

In our research, we are examining the correlation between participation in extracurricular and extraschool activities and the results of competency measurements in national assessment.

Our hypothesis: It is supposed that there is a correlation between the participation in development activities, talent development activities, and other school-based leisure activities and the competency performance (Báthory, 1997; Darvas \& Kende, 2010, Imre et al., 2015; Pusztai, 2015). We also supposed that there is a correlation between the students' participation in extraschool activities (private classes, out-of-school camps, extraschool activities) and high-performance of the national competence measurements (Bray, 1999; Gordon Gy ri, 2008; Imre et al., 2015; Pásku \& Münnich, 2000; Pusztai, 2015).

\subsection{Research methodology}

Our research sample consisted of students from the Hungarian 4th graders in Covasna County $(\mathrm{N}=1054)$. No background questionnaires are collected during the Romanian national competence measurements. Introducing a background questionnaire as part of the Grade 4 assessment will help to 
better understand the impact of contextual factors on student learning.

In order to explore the factors influencing the results of the competence measurements, we used a self-prepared background questionnaire. The questionnaire contains 19 questions about the student's school life, study situation, extracurricular and extraschool activities, reading habits, parents' education. The results of the competence measurement (the codes) were also filled in the table attached to the questionnaire. The survey was carried out in May 2017 during national measurements. We created our database from the results of the questionnaire and competency measurements. Based on our database (KOV-ET-OM-2017 Database), we analyze the relationship between participation in extracurricular, extraschool, after-lesson activities and the school performance. School performance is interpreted in terms of the results of national assessments. Our research is based on comprehensive data collection, so we cannot speak of a representative sample, but it does provide very useful information for drawing many lessons and shaping the educational strategy.

\section{Results of the research}

The national assessments are only coded, score values are assigned to the codes to allow statistical analysis of the results. Based on the scores, we divided students into three categories: low, medium and high performing.

Based on the results, $29.5 \%$ of the students were classified as high-performing from Hungarian competency test results (their mother tongue), 25.9\% from Romanian competency test results and $24.1 \%$ from mathematics test results. In the case of medium performance, $46.2 \%$ were classified from mathematics, $40.2 \%$ from Romanian, and 35\% from Hungarian. On the other hand, almost one third of the sample can be classified into the lowperforming category: $35.5 \%$ from Hungarian, 33.9\% from Romanian and $29.7 \%$ from mathematics fall into low performance categories. 
Table no. 1. Results of competency measurements

\begin{tabular}{lccc}
\hline & Hungarian & Romanian & Maths \\
\hline Low performance & $35.5 \%$ & $33.9 \%$ & $29.7 \%$ \\
\hline Medium performance & $35.0 \%$ & $40.2 \%$ & $46.2 \%$ \\
\hline High performance & $29.5 \%$ & $25.9 \%$ & $24.1 \%$ \\
\hline
\end{tabular}

Source: KOV-ET-OM-2017 database

3.1. Relationships between extracurricular school activities and school performance

First, we mapped the effects of extracurricular activities within the school. We wanted to find out whether there is a correlation between the participation in development activities, talent development activities, and other schoolbased leisure activities and the competency measurement results. The analysis revealed that the majority of students do not participate in extracurricular activities. There is a low participation rate in talent development activities, with $20.2 \%$ attending these activities. $70.3 \%$ of the students do not participate in leisure activities organized by the school. However, the lowest rate is participation in coaching/development activities, with only $14.2 \%$ of the sample being involved in such activities.

Table no. 2. Percentage of participation in extracurricular activities

\begin{tabular}{lccc}
\hline & $\begin{array}{c}\text { Free time } \\
\text { activities }\end{array}$ & $\begin{array}{c}\text { Talent developing } \\
\text { activities }\end{array}$ & $\begin{array}{c}\text { Coaching, developing } \\
\text { activities }\end{array}$ \\
\hline Take part & $29.7 \%$ & $20.2 \%$ & $14.2 \%$ \\
\hline Do not take part & $70.3 \%$ & $79.8 \%$ & $85.8 \%$ \\
\hline
\end{tabular}

Source: KOV-ET-OM-2017 database

No significant correlation was found between the results of the national assessments and the coaching/development and leisure activities organized within the school in any of the competencies.

However, when looking at the relationship between the school afternoon program and effectiveness, we find that only $18.6 \%$ of our sample require school after school activities. No significant correlation was found between the results of 
competency measurements and the participation in coaching/development and leisure activities organized within the school in any of the competencies.

This can be explained by the fact that many institutions in the county have not yet implemented the 'School after School' program. In many cases, it is not feasible due to funding problems, while in other situations, it is not undertaken by teachers, complaining about the fact that they are overloaded with work. According to our research results, of the pupils attending the after school programe only $25.4 \%$ are successful at Hungarian competency test, $23.7 \%$ at Romanians competency test and $22.9 \%$ at mathematics competency test. Of the children who take part in after school activities, $40.5 \%$ fall into low category at Hungarian, $40.3 \%$ at Romanian and $35.1 \%$ at mathematics in competency test results.

Table no. 3. The relationship between after-school activities and the results of the national assessments

\begin{tabular}{lccccccccc}
\hline & \multicolumn{3}{c}{ Hungarian } & \multicolumn{3}{c}{ Romanian } & \multicolumn{3}{c}{ Maths } \\
\hline & low & medium & high & low & medium & high & low & medium & high \\
\hline $\begin{array}{l}\text { Parents, } \\
\text { grandparents }\end{array}$ & $31.8 \%$ & $\underline{38.0 \%}$ & $30.3 \%$ & $31.2 \%$ & $42.6 \%$ & $26.2 \%$ & $26.0 \%$ & $48.9 \%$ & $25.1 \%$ \\
\hline After school & $40.5 \%$ & $34.1 \%$ & $25.4 \%$ & $\underline{40.3 \%}$ & $36.0 \%$ & $23.7 \%$ & $35.1 \%$ & $42.0 \%$ & $22.9 \%$ \\
\hline $\begin{array}{l}\text { Individual } \\
\text { study }\end{array}$ & $37.3 \%$ & $29.8 \%$ & $32.9 \%$ & $33.2 \%$ & $38.3 \%$ & $28.5 \%$ & $30.7 \%$ & $44.4 \%$ & $24.9 \%$ \\
\hline
\end{tabular}

NHungarian: 989, $P=0,006$, adj. resid $>2$ NRomanian: 1003, $P=0,048$, adj. resid $>2$ Nmaths: 1011, $P=0,007$, adj. resid $>3$

(In the table, we underlined the data of the cells that had more randomly distributed cells.

We also examined the effect of talent management activities and found a strong significant correlation $(\mathrm{p}=0.000)$ between the results of participation in talent management activities and the result of each of the three competence areas. Of those who take part in the school-organized talent-promotion activities, $41.7 \%$ at Hungarian, $39.4 \%$ at Romanian and $34.3 \%$ at mathematics fall into high performance categories, while those who do not attend the above activities $26.3 \%$ at Hungarian, at Romanian $22.5 \%$ and at Mathematics $21.7 \%$ fall into high performance categories. Even in the average successful group, those who participate in talent development are more likely to perform than those who do not. The results of the study confirm that the enrichment activity can become an effective complement to classroom instruction (Páskuné Kiss, 2014). 
Tabel no. 4. Relationships between participating in talent development and the results of the national assessments

\begin{tabular}{lccccccccccc}
\hline & \multicolumn{3}{c}{ Hungarian } & & & Romanian & & \multicolumn{2}{c}{ Maths } \\
\hline & low & medium & high & low & medium & high & low & medium & high \\
\hline Takes part & $19.4 \%$ & $38.8 \%$ & & $\underline{41.7 \%}$ & $20.7 \%$ & $39.9 \%$ & $\underline{39.4 \%}$ & $17.9 \%$ & $47.8 \%$ & $\underline{34.3 \%}$ \\
\hline $\begin{array}{l}\text { Does not } \\
\text { take part }\end{array}$ & $\underline{39.5 \%}$ & $34.2 \%$ & $26.3 \%$ & $\underline{37 \%}$ & $40.5 \%$ & $22.5 \%$ & $\underline{32.4 \%}$ & $45.9 \%$ & $21.7 \%$ \\
\hline
\end{tabular}

NHungarian: 984, NRomanian:999, Nmaths: 1006, Sig.***, Adj.resid>3

(In the table, we underlined the data of the cells that had more randomly distributed cells.)

We found a significant correlation between student performance and participation in school camps $(\mathrm{p}=0.000)$. In all three areas of competence, the benefits of attending a school camp can be demonstrated. Of the children who have taken part in school camps, 35\% at Hungarian, 29.6\% at Romanian and $29.2 \%$ at maths fall into high performance category, while $20.1 \%$ at Hungarian, $19.8 \%$ at Romanian and $16 \%$ at maths achieve high performance category from the non-participants. In terms of average performance, there is no significant difference between those who attend and do not attend school camps.

For all three areas of national assessment, we find that those who do not participate in the above mentioned and analysed activities are more likely to fall into the low performance category. In the context of increasing academic performance and extracurricular activities, it can be stated that "especially for students away from school culture, integration into the school normative system must first be promoted through inter- and intrageneration building relationships and building trust" (Pusztai, 2015, p. 36). A very good opportunity is provided by such activities.

Most interesting is the correlation between school-organized camps and the mother tongue competence measurements results. Here, too, it is noticeable that the average performance is less different between participants and non-participants. $35 \%$ of those who participate in camps achieve high results, while those who do not participate make up $20.1 \%$ of this category. There is also a striking difference between participants and non-participants: $45.7 \%$ of those who do not participate are among the low achievers, and only $29.6 \%$ of those who participate fall into this category. 
Table no. 5. Relationships between Hungarian/mother tongue performance and participation in school-organized camps

\begin{tabular}{llcccc}
\hline & & \multicolumn{3}{c}{ Hungarian/Mother tongue performance } \\
\hline \multirow{2}{*}{ Takes part } & $\%$ & Low performance & Medium performance & High performance \\
& Adj.resid & $29.6 \%$ & $35.4 \%$ & $35 \%$ \\
\hline \multirow{2}{*}{$\begin{array}{l}\text { Does not } \\
\text { take part }\end{array}$} & $\%$ & -5.0 & .4 & 4.8 \\
\hline
\end{tabular}

$N=942$, Sig. $* * *$

3.1. The relationships between shadow education/extraschool activities and school performance

The effect of camps organized outside the school on performance is similar to that of school camps ( $\mathrm{p}=0.000)$. From the participants, $35.7 \%$ at Hungarian, $31.2 \%$ at Romanian and $34.4 \%$ at maths achieved high performance. We can also state that $42.9 \%$ of non-participants at Hungarian, $38.8 \%$ at Romanian and $34.9 \%$ at mathematics are in the low performance group. With respect to average performance, it can be noted that, with the exception of mathematics, students enrolled in out-of-school camps have a higher proportion in the middle category than those who do not attend out-of-school camps).

Table no. 6. Relationships between participation in camps outside the school and the results of the national assessments

\begin{tabular}{lccccccccc}
\hline & \multicolumn{3}{c}{ Hungarian } & \multicolumn{3}{c}{ Romanian } & \multicolumn{3}{c}{ Maths } \\
\hline & low & medium & high & low & medium & high & low & medium & high \\
\hline $\begin{array}{l}\text { Takes } \\
\text { part }\end{array}$ & $26.4 \%$ & $37.9 \%$ & $\underline{35.7 \%}$ & $28.1 \%$ & $40.7 \%$ & $\underline{31.2 \%}$ & $21.7 \%$ & $43.9 \%$ & $\underline{34.4 \%}$ \\
\hline $\begin{array}{l}\text { Does } \\
\text { not take } \\
\text { part }\end{array}$ & $\underline{42.9 \%}$ & $32.3 \%$ & $24.8 \%$ & $\underline{38.8 \%}$ & $38.8 \%$ & $22.3 \%$ & $\underline{34.9 \%}$ & $48.1 \%$ & $17.0 \%$ \\
\hline
\end{tabular}

Nmaths: 946, NHungarian: 925, NRomanian: 940, Sig.***, Adj.resid>3

(In the table, we underlined data for cells that have more random distribution)

Examining the effects of private lessons, we found that our results did not show a significant correlation between mathematics lessons and competency measurement. 
Table no.7. Relationships of participation in sports, foreign language and music in private lessons and the results of the national assessments

\begin{tabular}{|c|c|c|c|c|c|c|c|c|c|c|}
\hline & \multicolumn{4}{|c|}{ Hungarian } & \multicolumn{3}{|c|}{ Romanian } & \multicolumn{3}{|c|}{ Maths } \\
\hline & & low & medium & high & low & medium & high & low & medium & high \\
\hline \multirow[t]{2}{*}{ Sports } & $\begin{array}{l}\text { Takes } \\
\text { part }\end{array}$ & $21.7 \%$ & $39.1 \%$ & $\underline{39.1 \%}$ & $19.6 \%$ & $\underline{48.8 \%}$ & $\underline{31.5 \%}$ & $14.2 \%$ & $44.6 \%$ & $\underline{41.2 \%}$ \\
\hline & $\begin{array}{l}\text { Does } \\
\text { not } \\
\text { take } \\
\text { part }\end{array}$ & $\underline{40.2 \%}$ & $33.7 \%$ & $26.1 \%$ & $\underline{38.8 \%}$ & $37.3 \%$ & $24.0 \%$ & $\underline{35.0 \%}$ & $46.7 \%$ & $18.2 \%$ \\
\hline \multirow[t]{2}{*}{ Music } & $\begin{array}{l}\text { Takes } \\
\text { part }\end{array}$ & $13.0 \%$ & $39.0 \%$ & $\underline{48.0 \%}$ & $19.0 \%$ & $43.0 \%$ & $\underline{38.0 \%}$ & $10.9 \%$ & $45.5 \%$ & $\underline{43.6 \%}$ \\
\hline & $\begin{array}{l}\text { Does } \\
\text { not } \\
\text { take } \\
\text { part }\end{array}$ & $\underline{38.0 \%}$ & $34.7 \%$ & $27.4 \%$ & $\underline{35.5 \%}$ & $39.9 \%$ & $24.6 \%$ & $\underline{31.7 \%}$ & $46.3 \%$ & $22.0 \%$ \\
\hline \multirow[t]{2}{*}{$\begin{array}{l}\text { Foreign } \\
\text { language }\end{array}$} & $\begin{array}{l}\text { Takes } \\
\text { part }\end{array}$ & $18.2 \%$ & $41.8 \%$ & $\underline{40.0 \%}$ & $20.7 \%$ & $\underline{49.5 \%}$ & $29.7 \%$ & $12.5 \%$ & $50.0 \%$ & $37.5 \%$ \\
\hline & $\begin{array}{l}\text { Does } \\
\text { not } \\
\text { take } \\
\text { part }\end{array}$ & $\underline{37.7 \%}$ & $34.2 \%$ & $28.1 \%$ & $\underline{35.4 \%}$ & $39.1 \%$ & $25.4 \%$ & $\underline{31.8 \%}$ & $45.7 \%$ & $22.5 \%$ \\
\hline
\end{tabular}

NHungarian: 984, NRomanian: 999, Nmaths: 1006, Sig.***, Adj.resid>3. (In the chart, we underlined data for cells where more than the random distribution is located)

A strong significant correlation $(\mathrm{p}=0.000)$ was found between foreign language, music and sports activities out of school and performance. The sports, art, academic activities outside the classroom have a positive effect on performance (Pusztai, 2015). About $41.2 \%$ of the participants registered in sports activities fall into the high performance zone and only $14.2 \%$ into the low performance category. While only $18.2 \%$ of those who do not participate can be classified as high achievers. There is a slight difference in average performance between those who attend (44.6\%) and those who do not attend sports $(46.7 \%)$. There is a strong correlation between attending music and competence measurements results. Those who do not attend private music classes are more likely to fall into the low category in all three measurement areas. The impact of a foreign language is also very pronounced: $40 \%$ of those who take private lessons in a foreign language are included in the high performance category for native speakers. In the Romanian language area, 29.7\% are classified as high-performing. Analyzing the impact of sports, foreign language and music private lessons, we can conclude that the benefits of participating in these activities are evident in all three areas of competence. The sports, music and foreign language extracurricular activities seem to be effective extracurricular investments, as their positive effect is confirmed in mathematical and linguistic outcomes (Pusztai, 2015). Our results are in unison with the outcomes of other similar 
researches which show that supplementary private education may apply to educational content/areas such as mathematics that every student must master at a certain level, but can also target other areas such as music education, art education, and various sports (Gordon Gy ri, 2008).

Positive effects of out-of-school clubs are also evident in the study. Significant correlation can be found between out-of-school visits and competency assessment results. Those who participate in such activities are much more likely to be classified in the high performance group than those who do not attend extracurricular activities.

Table no. 8. Relationships between extracurricular activities and the results of the national assessments

\begin{tabular}{lccccccccc}
\hline & \multicolumn{3}{c}{ Hungarian } & \multicolumn{3}{c}{ Romanian } & \multicolumn{3}{c}{ Maths } \\
\hline & low & medium & high & low & medium & high & low & medium & high \\
\hline $\begin{array}{l}\text { Takes } \\
\text { part }\end{array}$ & $22.1 \%$ & $34.8 \%$ & $\underline{43.1 \%}$ & $25.3 \%$ & $39.7 \%$ & $\underline{35.0 \%}$ & $15.4 \%$ & $47.1 \%$ & $\underline{37.5 \%}$ \\
$\begin{array}{l}\text { Does not } \\
\text { take part }\end{array}$ & $\underline{42.3 \%}$ & $35.3 \%$ & $22.4 \%$ & $\underline{38.2 \%}$ & $40.5 \%$ & $21.4 \%$ & $\underline{36.8 \%}$ & $45.9 \%$ & $17.3 \%$ \\
\hline
\end{tabular}

NHungarian: 984, NRomanian: 999, Nmaths: 1006, Sig.***, Adj.resid>3.

(In the table, we underlined the data of the cells that had more randomly distributed cells)

The highest rate can be observed in the field of Hungarian competency measurement results: $43.1 \%$ of the participants in the professional groups are in the high performance group, compared to $35 \%$ in Romanian and $37.5 \%$ in mathematics. Regarding low efficiency, $42.3 \%$ at Hungarian, $38.2 \%$ at Romanian, and $36.8 \%$ at maths have poor results. There is no significant difference in medium scores between those who attend and those who do not attend extracurricular activities. Strong significance $(\mathrm{p}=0.000)$ can be detected if parents' educational level and participation in extracurricular activities and camps are examined. Similarly, there is a strong correlation $(p=0.000)$ between participation in activities in these areas of shadow education and the labor market situation of parents. The children of parents with higher education and regular employment are more involved in these activities.

\section{Discussion}

In our analysis, we focused on the effects of extracurricular activities organized by the school and extraschool activities/shadow education. Our 
results show that there is no significant correlation in terms of performance and the participation in extracurricular activities, except of talent management activities and school camps. We found a weak significant relationship between afternoon school activity and effectiveness. A school-after-school program would be important in overcoming disadvantages and increasing equal opportunities if content and quality are appropriate. However, pushing time frames alone will not lead to increased efficiency. The proportion of participants in the coaching/development and leisure activities is very low, but the results of the national competency assessment show that there is a great need for such programs and activities. If out-of-class activities are being incorporated into an all-day school program, the benefits of these activities could be manifested within appropriate organizational frameworks, implemented with quality content. If we look at the mother tongue results, in line with Pletl's (2012) research, we find that the proportion of highperforming individuals decreases and the average layer's performance slips below the $50 \%$ performance range. This draws attention to the fact that students with low levels of reading literacy in primary education are no longer able to catch up. Therefore, greater involvement of students in appropriate corrective, development and/or compensatory activities is essential.

The benefits of extraschool activities, music, foreign language and sports, private lessons/activities, and the various camps are clearly demonstrated in all three areas of competences. Our research results show a significant correlation between performance and attendance of extraschool activities. The beneficial effects of activities in different areas of shadow education are evident, but in many cases parents have to pay, which is almost impossible for disadvantaged families. In addition to the beneficial effects of shadow education, it should also be mentioned that it greatly enhances educational inequalities.

The right content and quality are essential for successful development activities and preparation for school afternoons. In order to compensate for the disadvantages, schools should pay particular attention to integrating students into the school standard system, offering a wealth of communitybuilding extracurricular activities and successfully implementing the afterschool program. By spending time on preparing for the day ahead, together with well-organized, quality leisure content and personality development activities, in the gap between those with different socio-economic status 
can be reduced and school performance increased.

\section{NOTES}

1 MEN and WB (2015), Strategy on reducing early school leaving, Bucharest, available at http://www.edu.ro/sites/default/files/_fi\%C8\%99iere/InvatamantPreuniversitar/2015/Strategie-PTS /Strategia-PTS-2015.pdf.

2 ORDER for the modification and completion of the Methodology for organizing the 'School after school' Program, approved by Order of the Minister of Education, Research, Youth and Sports no. 5349/2011 in accordance with Government Decision no. 26/2017.

\section{References}

- Bacskai, K. (2015). Iskolák a társadalom peremén. Belvedere Meridionale Kft.

- Báthory, Z. (1997). Tanulók, iskolák, különbségek. Okker Kiadó.

- Bray, M. (1999). The Shadow Education System: Private Tutoring and its Implications or Planners. Fundamentals of Educational Planning No. 61. UNESCO International Institute for Educational Planning.

- Bray, M. (2010). Researching Shadow Education: methodological challenges and directions. Asia Pacific Education Review, 11, 3-13. https://doi.org/10.1007/s12564-009-9056-6

- Bourdieu, P. (1999). Gazdasági tõke, kulturális tõke, társadalmi tõke. In R. Angelusz (Ed.), A társadalmi rétegzõdés komponensei (pp. 156-178). Új Mandátum Kiadó.

- Buda, A. (2011). Értékelési filozófiák és pedagógiai mérés. Debreceni Egyetem Tudományegyetemi Karok.

- Darvas, Á., \& Kende, Á. (2009). Az egész napos iskola nemzetközi tapasztalatai, hazai lehetõségei. Esély.

http://www.esely.org/kiadvanyok/2010_3/02darvaskende.indd.pdf

- Fehérvári, A. (2015). A hátrányos helyzetû tanulók oktatásának változása 20062014. In A. Fehérvári \& G. Tomasz (Eds.), Kudarcok és megoldások. Iskolai hátrányok, lemorzsolódás, problémakezelés (pp. 32-52). Oktatáskutató és Fejlesztõ Intézet.

- Fóris-Ferenczi, R. (2008). A tervezéstõl az értékelésig. Tanterv-és értékeléselmélet. Ábel Kiadó, Kolozsvár.

- Fûz, N. (2017). Iskolán kívüli színterek az általános iskolai oktatásban. Magyar Pedagógia, 117(2), 197-220.

- Fûz, N. (2018). Az iskolán kívüli tanórák hatékonyságának megítélése általános iskolás diákok és pedagógusok körében. Iskolakultúra, 28(8-9), 38-53. 
- Gordon Gyõri, J. (1998). Mitõl hatékony még a japán oktatás? Magyar Pedagógia, 4(98), 273-317.

- Gordon Gyõri, J. (2008). Tömegoktatás és kiegészítõ magánoktatás-ipar. Educatio, 2, 263-274.

- Imre, A. (2016). Lehetõségek és akadályok a tanórán kívüli tanulásban: délutáni foglalkozások és pedagógusi munkaterhek. In M. Szemerszki (Ed.), Hátrányos helyzet és iskolai eredményesség (pp. 75-100). Oktatáskutató és Fejlesztõ Intézet.

- Imre, A. (2015). Eredményesség és társadalmi beágyazottság. Oktatáskutató és Fejlesztõ Intézet.

- Imre, A. et al. (2015). Az iskolai tanulás (idõ) kereteink és határainak kérdései nemzetközi tapasztalatok tükrében. In A. Imre (Ed.), Eredményesség és társadalmi beágyazottság (pp. 37-50). Oktatáskutató és Fejlesztõ Intézet.

- MEN \& BM. (2015). Strategia privind reducerea părăsirii timpurii a şcolii. http://www.edu.ro/sites/default/files/_fi\%C8\%99iere/Invatamant-Preuniversitar/ 2015/Strategie-PTS/Strategia-PTS-2015.pdf

- Mihály, I. (2004). Tanulás „árnyékban”, avagy a tanügyi második gazdaság mûködése. Új Pedagógiai Szemle.

- Páskuné Kiss, J. (2014). Tanórán kívüli iskolai és iskolán kívüli programok a tehetséggondozásban. Magyar Tehetségsegítõ Szervezetek Szövetsége.

- Pásku, J., \& Münnich, Á. (2000). Az extrakurrikuláris oktatás nem specifikus hatásai. Magyar Pedagógia, 100(1), 59-77.

- Péter, L. (2012). Reform és visszhangok. A közoktatási reform fogadtatása romániai magyar pedagógusok körében. Kolozsvári Egyetemi Kiadó, Kolozsvár.

- Pletl, R. (2012). Helyzetjelentés az erdélyi magyar diákok olvasási és szövegértési képességének színvonaláról. Ábel Kiadó, Kolozsvár.

- Pusztai, G. (2009). A társadalmi tõke és az iskola. Kapcsolati erõforrások hatása az iskolai pályafutásra. Új Mandátum Könyvkiadó.

- Pusztai, G. (2015). Az eredményesség kapcsolati beágyazottsági háttere. In A. Imre (Ed.), Eredményesség és társadalmi beágyazottság (pp. 23-36). Oktatáskutató és Fejlesztõ Intézet.

- Szántó, B. (2015). A IV. osztályos tanulók anyanyelvi szövegértésének szintje a 2013/2014-es országos felmérések tükrében. PedActa, 5(1), 1-10.

http://padi.psiedu.ubbcluj.ro/pedacta/article_5_1_1.pdf

- Stevenson, D. L., \& Baker, D. P. (1992). Shadow education and allocation in formal schooling: Transition to university in Japan. American Journal of Sociology, 97(6), 1639-1657.

- Széll, K. (2015). Szegregáció és hátránykompenzáció - Pedagógusattitûdök. In A. Fehérvári \& G. Tomasz (Eds.), Kudarcok és megoldások. Iskolai hátrányok, lemorzsolódás, problémakezelés (pp. 53-72). Oktatáskutató és Fejlesztõ Intézet.

- Singer, F. M. (2013). Romanian Research in Education: Where to?. Revista de Politica Ştiin ei şi Scientometrie, 2(4), 286-302. 
The online version of this article can be found at: http://revped.ise.ro/category/2020-en/

\section{$( \mathrm { Cc } ) \longdiv { \mathrm { B } - \mathrm { Ne } - \mathrm { BA } }$}

This work is licensed under the Creative Commons Attribution-NonCommercial-ShareAlike 4.0 International License.

To view a copy of this license, visit http://creativecommons.org/licenses/by-nc-sa/4.0/ or send a letter to Creative Commons, PO Box 1866, Mountain View, CA 94042, USA.
Versiunea online a acestui articol poate fi găsită la: http://revped.ise.ro/category/2020-ro/

\section{(oc) EY-NC-SA}

Această lucrare este licen iată sub Creative Commons Attribution-NonCommercial-ShareAlike 4.0 International License.

Pentru a vedea o copie a acestei licen e, vizita $i$ http://creativecommons.org/licenses/by-nc-sa/4.0/ sau trimite i o scrisoare către Creative Commons, PO Box 1866, Mountain View, CA 94042, SUA. 